IRSTI 31.23.17

\author{
${ }^{1 *}$ M.Zh. Zhumagul, ${ }^{1}$ M.S. Kurmanbayeva, ${ }^{2}$ N.O. Kudrina, \\ ${ }^{1}$ K.D. Tolenova, ${ }^{3}$ A.S. Seilkhan, ${ }^{4}$ Mária Höhn \\ ${ }^{1}$ Laboratory of plant anatomy and morphology, Almaty, Kazakhstan \\ ${ }^{2}$ Central Laboratory for Biocontrol, Almaty, Kazakhstan \\ ${ }^{3}$ Kazakh National Agrarian University, Almaty, Kazakhstan \\ ${ }^{4}$ Szent István University, Budapest, Hungary \\ *e-mail: moldirzhumagul@gmail.com
}

\title{
GC-MS analysis of the lipophilic compounds of medicinal plant Rhodiola rosea $\mathrm{L}$.
}

\begin{abstract}
Rhodiola (R.) rosea L. is one of the most popular adaptogenic agents. Rhodiola rosea L. (fam. Crassulaceae) commonly known as golden root or roseroot, is an insect-pollinated dioecious perennial that has been traditionally used as an immunomodulatory agent in many countries, including Kazakhstan. Plant extracts can be used both against somatic and infectious diseases, psychiatric and neurological diseases as well as in healthy people to relieve fatigue and increase concentration, memory, and productivity. There is growing evidence that the long-term effects of stressful life events and depression are associated with significant behavioral, endocrinological and neurobiological changes in human. $R$. rosea is a relatively rare and valuable medicinal plant and grows at high altitudes (up to $2280 \mathrm{~m}$ above the sea level) in the arctic and mountainous regions of Central Asia, Europe and North America. Study of the phytochemical composition of $R$. rosea is required in order to introduce it into official practice. Several mechanisms of action that are potentially responsible for the observed stress resistance, anti-aging and anti-cancer effects of $R$. rosea extracts and its active compounds have been identified in in vitro cell culture systems and on in vivo animal models. $R$. rosea extracts and its main biologically active compound salidroside appear to have multi-targeted effects. The results of our research showed that $R$. rosea in addition to adaptogenic, has several other pharmacological properties: antioxidant, antidepressant, immunomodulatory. Phytochemical study of $R$. rosea in Kazakhstan has been conducted for the first time. As a result of the conducted work, 28 compounds were identified in its composition.
\end{abstract}

Key words: Rhodiola rosea L., phytochemical composition, medicinal plants, extracts, biological activity, essential oil, pharmacotherapeutic group.

\section{Introduction}

The flora of Kazakhstan includes 68 species of trees, 266 species of shrubs, 433 species of semishrubs and semi-herbs, 2,598 species of perennial grasses, 849 species of annual herbs. There are more than six thousand plant species in Kazakhstan, of which 515 are endemics, 303 plant species are listed as rare and endangered, including various groups of useful plants. Crassulaceae family concludes 30 genera and about 1,500 varieties of succulent plants, out of which some are included into the Red Book of Kazakhstan, including Rhodiola (R.) rosea L. [1-3].

Healing potential of its extracts is known for many centuries. As previously, medicinal plants sustain as sources of necessary compounds for the maintenance of vital activity. The range of biologically active compounds based on medicinal and food plants used in medical practice, food industry and agriculture has however enlarged. It is important to emphasize that naturally produced biologically active compounds have pronounced physiological effect on the body and its main regulatory and metabolic processes, with lack of additive effects [4].

The importance of biologically active compounds as protective agents that prevent diseases, including such caused by adverse environmental factors and stresses is obvious. Some medicinal plants stand out for their stimulating effects on the immune system of the body and prevention of various pathological processes. One of such plants is $R$. rosea or golden root $[5 ; 6]$. 
$R$. rosea is a widespread and very polymorphic species, i.e. morphological features of this plant in different habitats vary greatly. This applies primarily to the number and density of branches, location of leaves and inflorescences, their shape and size [7-9].

Its root is a strong stimulant and increases the resistance of the human body to adverse factors. Rhizome resembles a human hand with five half-bent fingers, it is almost on the surface of the soil, and the coniferous roots go deep inside. Brownish rhizome is covered with scaly leaves of golden color with a peculiar pearlescence [10].

Leaves are pulpy, oblong-ovoid and pointed at the end. Flowers are yellow and collected in dense corymbose inflorescence. Male and female flowers are located on different bushes, male flowers are brighter and more visible, female flowers often remain green even during the flowering. Fruits - oblong leaflets of red or green color, $6-8 \mathrm{~mm}$ in length. Seeds are very small and light, up to $2 \mathrm{~mm}$ in length [11-13].

According to the literature sources 23 compounds of different nature: flavonoids, phenylpropanoids, flavolignans, monoterpenes and sterols were isolated from $R$. rosea rhizome, including such compounds as phenylpropanoids - rosin, rosavin, rosarin, cinnamon alcohol, caffeic acid, phenolic compounds tyrosol, salidroside, gallic acid, gallicin (methyl gallate), flavonoids - rhodiolin (flavolignan gerbecetin), rhodionine, rhoiosin, 3-methyl, 3-methyl-gallate, 3-methylate, rhodoline, rhodoline, 3-methyl-gallate, rhodoline, 3-methyl-gallate, rhodoline, 5-methyl-galvanic acid, rhodoline, 5-sylphane, rhodoline, 3-methyl-gallate; tricine, tricine-5-O-glucoside, terpenoids - rosidol, roziridin, $\beta$-sitosterol, daucosteric [14-20].

Essential oils of $R$. rosea, making 0.03 to $0.2 \%$ of total compounds, vary and are of particular interest to the modern cosmetics industry. For instance, $R$. rosea, which grows in Norway, contains such components as monoterpenic acids, monoterpenic alcohols, and aliphatic alcohols in the composition of essential oils. Geraniol, in ratio of up to $65 \%$, is a key component affecting its smell. Geranyl acetate, benzyl alcohol, phenylethyl alcohol, geranyl formate are also contained in the essential oil. The enhancers of the flower odor of the rhizomes of the $R$. rosea are linalool and its oxides, nonanal, decanal, nerol and cinnamon alcohol [20-22].

$R$. rosea may affect cognitive function and general nervous system. It was revealed that after a course of treatment with $R$. rosea extract significant improvement in the central nervous system occurs as the root extract increases such indicators as mobility and strength. In patients with neuroses, there is an improvement in sleep, memory, attention, and appetite; the increased irritability and unpleasant vibrations in the heart region disappear. In pharmacology, the liquid extract of $R$. rosea has a positive effect on the correction of the side effects of psychotropic therapy for schizophrenia, Parkinsonism, asthenia, etc. $[23 ; 24]$. In addition, $R$. rosea helps to prevent the negative effects of free radicals [25].

$R$. rosea as an adaptive organism resists the effects of chemical, biological, physical stress. In turn, the adaptogen is a catalyst for resistance to significant number of human diseases and enhances the metabolism that stimulates the hypothalamic-pituitaryadrenal system, which contributes to the processes of synthesis, improves oxygen transport to muscles and nervous system, and affects the development of red blood cells and resistance to hypoxic stress [26; 27].

Results of many studies have shown that $R$. rosea root extract stimulates and increases physical performance [9-14]. Under the experimental conditions, the possibility of correcting the free radical oxidation of membrane lipids in the blood plasma and liver tissue of animals by introducing adaptogens of extracts of Eleutherococcus (E.) senticosus, R. rosea and Glycyrrhiza glabra was investigated. Their effectiveness has been shown to increase the body's resistance under stress conditions - the effects of prooxidant factors, such as cold load and ultraviolet radiation. The administration of extracts of E. senticosus and $R$. rosea has a more pronounced antioxidant effect and stress-protective activity under conditions of induction of lipid peroxidation by exposure to cold, as evidenced by a decrease in the content of peroxidation products in the blood and liver of animals [28].

Currently, the possibility of using $R$. rosea preparations as hepatoprotectors is widely considered. That is, the pharmacotherapeutic group of dissimilar drugs, which prevent the destruction of cell membranes and stimulate the regeneration of hepatocytes, thereby exerting a positive effect on liver function [29].

Considering the unique medicinal properties of $R$. rosea, it is necessary to study its phytochemical composition.

\section{Materials and methods}

The object of the study is the aerial part of $R$. rosea, harvested in the flowering phase in the highlands of the Kazakhstani part of the Altai mountain system (Figure 1). Raw materials collected and dried in accordance with the requirements of the State Pharmacopoeia of the Republic of Kazakhstan, ${ }^{\text {st }}$ edition $[30 ; 31]$. 
The crushed air-dry raw material was subjected to extraction by the method of infusion (maceration) with $96 \%$ ethanol, at the room temperature for 3 days. Extraction was repeated twice. The combined extract was concentrated and dried under vacuum.

Research was carried out in the Laboratory Ecology of the Biosphere, RSE Al-Farabi KazNU, SSE Center for Physical and Chemical Methods of Research and Analysis, and Laboratory of plant anatomy and morphology, Al-Farabi KazNU (Figure 2).

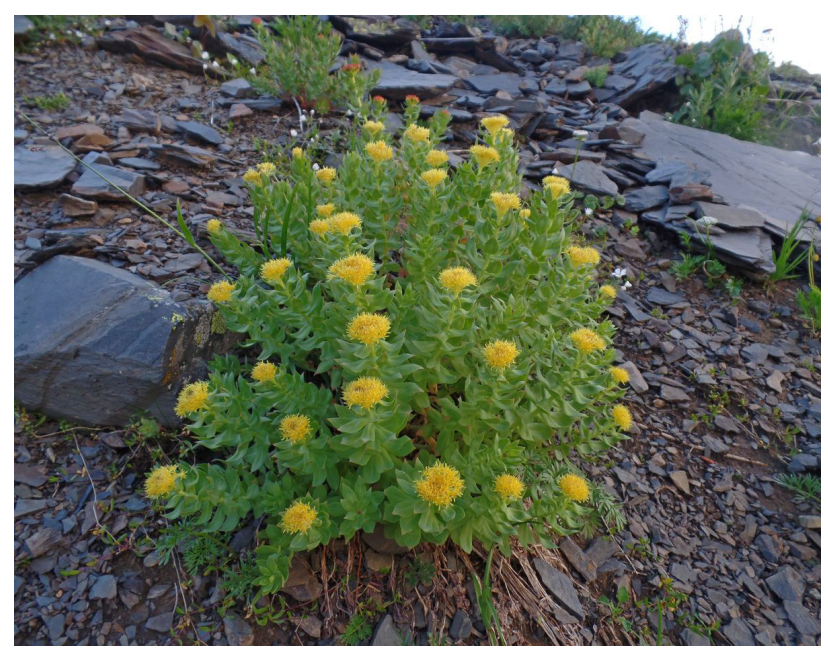

Figure 1 - Altai's $R$. rosea. Flowering stage. Kazakhstan, East Kazakhstan region, the northern slope of the Ivanovsky Belok ridge, 1800 m. above s.1., August 2017. Photo by Olga Kuznetsova

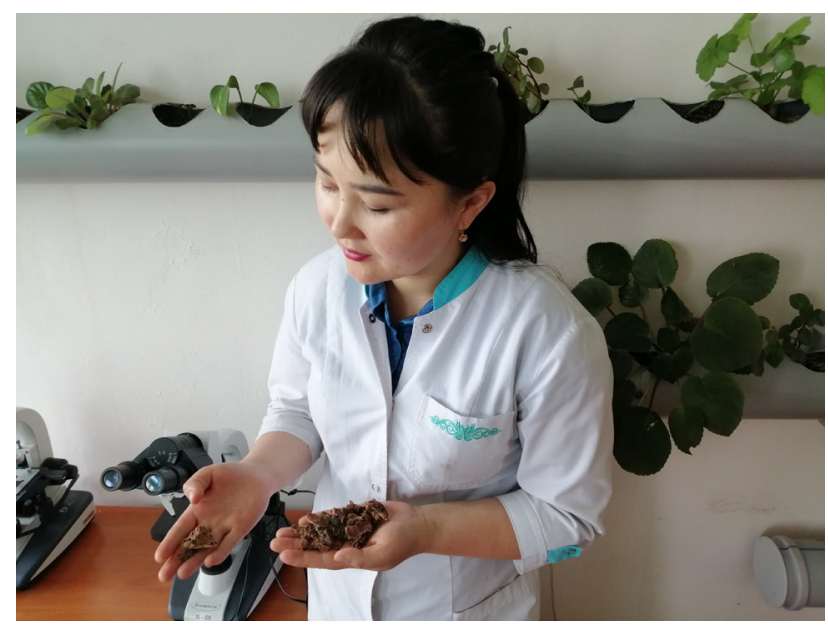

Figure 2 - Work with Rhodiola rosea L. at the laboratory of plant anatomy and morphology, KazNU, by Moldir Zhumagul
For the identification and quantitative estimation of compounds in the plant sample method using gas chromatography-mass spectrometry (GC-MS, Agilent 6890N/5973N, USA) was applied. Analysis conditions: sample volume $0.5 \mu \mathrm{l}$, sample entry temperature $250{ }^{\circ} \mathrm{C}$, without dividing the flow. The separation was carried out using a DB-WAXetr (Agilent, USA) chromatographic capillary column with a length of $30 \mathrm{~m}$, an internal diameter of $0.25 \mathrm{~mm}$ and a film thickness of 0.25 $\mu \mathrm{m}$ at a constant carrier gas (helium) rate of $1 \mathrm{~mL} /$ min. The chromatographic temperature was programmed from $40{ }^{\circ} \mathrm{C}$ (holding $0 \mathrm{~min}$ ) to $200{ }^{\circ} \mathrm{C}$ with a heating rate of $10{ }^{\circ} \mathrm{C} / \mathrm{min}$ (holding $15 \mathrm{~min}$ ). Detection was carried out on the SCAN mode $\mathrm{m} / \mathrm{z}$ 34-750. Agilent MSD ChemStation software was used to control the gas chromatography system, record and process the results and data obtained (version 1701EA). Data processing included evaluation of retention times, peak areas, as well as processing of spectral information obtained using a mass spectrometric detector. The Wiley $7^{\text {th }}$ edition and NIST'02 libraries were used to decipher the mass spectra obtained (total number of spectra in libraries - more than 550,000 units).

\section{Results and discussion}

Gas-liquid chromatography is used for the analysis, separation and purification of synthetic polymers, drugs, detergents, proteins, hormones and other biologically important compounds. The use of highly sensitive detectors allows working with tiny amounts of compounds $\left(10^{-11}-10^{-9} \mathrm{~g}\right)$, which is extremely important in the biological research.

In this regard, the composition of the obtained extract was analyzed.

GC-MS chromatogram of $R$. rosea ethanol extract is presented on Figure 3.

As a result of the study of the chemical composition of ethanol extract of $R$. rosea, obtained by treating the raw material with $96 \%$ ethanol, 28 components of different chemical nature were identified using GC-MS technique (Figure 3). The results of the analysis allow us to describe compounds whose content exceeded $0.5 \mathrm{mg} \%$. 


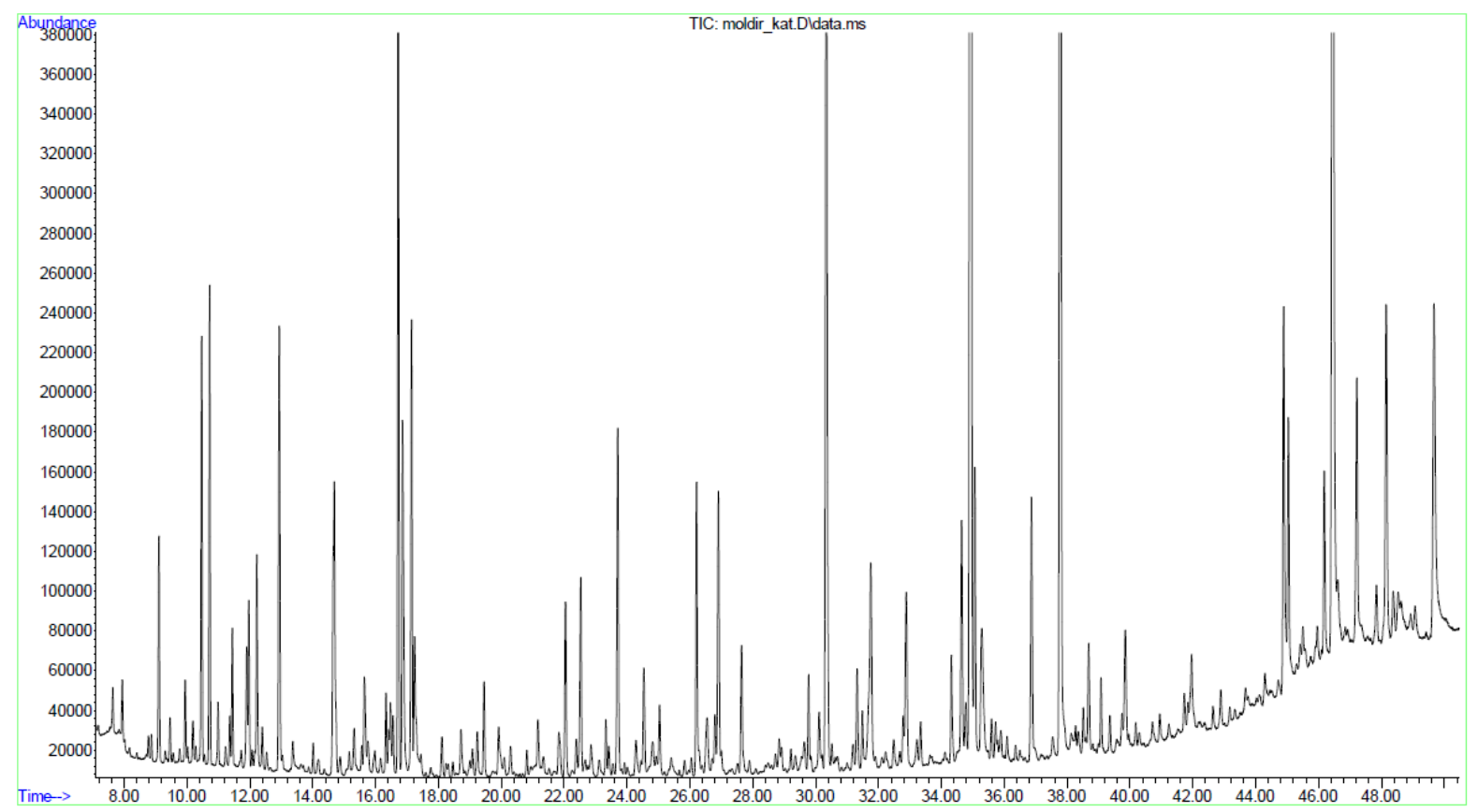

Figure 3 - Chromatogram of GC-MS analysis of $R$. rosea ethanol extract

Table 1 - The results of chromatographic analysis of the extract

\begin{tabular}{|c|c|c|c|c|c|c|}
\hline No. & RT & Compound & Formula & $\begin{array}{l}\text { Percent- } \\
\text { age, } \%\end{array}$ & Activity & $\begin{array}{l}\text { Litera- } \\
\text { ture }\end{array}$ \\
\hline 1 & 9.11 & $\begin{array}{c}\beta \text {-pinene } \\
\text { beta-pinene; 6,6-dimethyl-2- } \\
\text { methylenebicyclo } \\
\text { [3.1.1]-heptane }\end{array}$ & $\mathrm{C}_{10} \mathrm{H}_{16}$ & 0.98 & $\begin{array}{l}\text { anti-inflammatory, } \\
\text { antiviral } \\
\text { antimicrobial activities }\end{array}$ & [32] \\
\hline 2 & 10.72 & $\begin{array}{l}\text { 1,3-cyclopentadiene, } \\
\text { 5,5-dimethyl-2-ethyl }\end{array}$ & $\mathrm{C}_{9} \mathrm{H}_{14}$ & 1.99 & $\begin{array}{l}\text { flavoring spirits, } \\
\text { used to extract oils and fats }\end{array}$ & [33] \\
\hline 3 & 11.97 & $\begin{array}{l}\text { benzene-1-methyl-3-(1- } \\
\text { methyl-1) }\end{array}$ & $\mathrm{C}_{10} \mathrm{H}_{14}$ & 0.70 & $\begin{array}{l}\text { antiinflammatory, } \\
\text { used in perfumery for its citrus effect }\end{array}$ & [34] \\
\hline 4 & 12.22 & $\begin{array}{c}\text { ethanone, 2-hydroxy-1- } \\
\text { phenyl } \\
\end{array}$ & $\mathrm{C}_{8} \mathrm{H}_{8} \mathrm{O}_{2}$ & 1.01 & $\begin{array}{l}\text { antiseptic, used as a disinfecting and } \\
\text { drying agent and antiseptic }\end{array}$ & {$[35]$} \\
\hline 5 & 12.93 & $\begin{array}{c}\text { 2-propanone, } \\
\text { 1-hydroxy }\end{array}$ & $\mathrm{C}_{9} \mathrm{H}_{12} \mathrm{O}$ & 2.20 & antiseptic & [36] \\
\hline 6 & 14.68 & $\begin{array}{c}\text { citral (lemarome, } \\
\text { 3,7-dimethyl-2,6-octadienal) }\end{array}$ & $\begin{array}{c}\left(\mathrm{CH}_{3}\right)_{2} \mathrm{C}= \\
\mathrm{CHCH}_{2} \mathrm{CH}_{2} \mathrm{C}(\mathrm{CH} 3) \\
=\mathrm{CHCHO}\end{array}$ & 2.38 & $\begin{array}{l}\text { antiseptic and antiinflammatory, used in } \\
\text { perfumery for its citrus effect, } \\
\text { used as a flavor and for fortifying lemon } \\
\text { oil, has strong antimicrobial qualities, } \\
\text { and pheromonal effects in insects, used } \\
\text { in the synthesis of vitamin A, } \\
\text { ionone and methylionone }\end{array}$ & [37] \\
\hline 7 & 16.72 & $\begin{array}{l}\text { 2.6-dimethyl-1,3,5,7- } \\
\text { octatetraene }\end{array}$ & $\mathrm{C}_{10} \mathrm{H}_{16} \mathrm{O}$ & 4.03 & antiseptic, used as bactericidal agent & [38] \\
\hline 8 & 16.86 & acetic acid & $\mathrm{CH}_{3} \mathrm{COOH}$ & 2.25 & $\begin{array}{c}\text { antiseptic, used as a fungicide and } \\
\text { bactericidal agent }\end{array}$ & [39] \\
\hline 9 & 17.14 & $\begin{array}{l}\text { propanoic acid, 2-oxo-, } \\
\text { methyl ester }\end{array}$ & $\mathrm{C}_{4} \mathrm{H}_{6} \mathrm{O}_{3}$ & 2.01 & $\begin{array}{l}\text { antioxidant, has propionic acid, inhibits } \\
\text { the growth of mold and some bacteria }\end{array}$ & {$[40]$} \\
\hline 10 & 22.04 & 2-furanmethanol & $\mathrm{C}_{5} \mathrm{H}_{6} \mathrm{O}_{2}$ & 0.96 & $\begin{array}{l}\text { used to dissolve nitrocellulose, GOST } \\
\text { 28960-91 Furfuryl Alcohol }\end{array}$ & [40] \\
\hline
\end{tabular}


Continuation of table 1

\begin{tabular}{|c|c|c|c|c|c|c|}
\hline No. & RT & Compound & Formula & $\begin{array}{c}\text { Percent- } \\
\text { age, } \%\end{array}$ & Activity & $\begin{array}{c}\text { Litera- } \\
\text { ture }\end{array}$ \\
\hline 11 & 23.70 & 2.6-octadienal, 3,7-dimethyl- & $\mathrm{C}_{10} \mathrm{H}_{16} \mathrm{O}$ & 1.81 & $\begin{array}{l}\text { antiseptic and } \\
\text { antiinflammatory, used in perfumery } \\
\text { for its citrus effect }\end{array}$ & {$[41]$} \\
\hline 12 & 26.21 & geraniol & $\mathrm{C}_{10} \mathrm{H}_{18} \mathrm{O}$ & 1.53 & $\begin{array}{l}\text { used for making perfume compositions, } \\
\text { flavoring soap and detergent, used in } \\
\text { synthesis of other fragrant substances }\end{array}$ & {$[42]$} \\
\hline 13 & 26.90 & benzyl-alcohol & $\mathrm{C}_{7} \mathrm{H}_{8} \mathrm{O}$ & 1,45 & $\begin{array}{l}\text { flavoring, psychostimulant, appetite } \\
\text { regulator, used for disinfection of oil } \\
\text { solutions of drugs for intramuscular } \\
\text { injection in pharmacology }\end{array}$ & {$[43]$} \\
\hline 14 & 30.33 & cinnamaldehyde & $\mathrm{C}_{9} \mathrm{H}_{8} \mathrm{O}$ & 6,26 & $\begin{array}{c}\text { hypoglycemic agent, EC 4.3.1.24 } \\
\text { inhibitor (phenylalanine ammoniales), } \\
\text { vasodilator agent, antifungal agent }\end{array}$ & [44] \\
\hline 15 & 31.75 & $\begin{array}{l}\text { 1,3-diaxol -2-one, } \\
\text { 4.5-dimethyl- }\end{array}$ & & 1,81 & antiviral activity & {$[45]$} \\
\hline 16 & 32.88 & $\begin{array}{l}\text { 2-hydroxy-gamma- } \\
\text { butyrolactone }\end{array}$ & $\mathrm{C}_{4} \mathrm{H}_{6} \mathrm{O}_{3}$ & 1.15 & $\begin{array}{c}\text { EC 4.3.1.24 inhibitor, flavoring agent, } \\
\text { plant metabolite and sensitizer }\end{array}$ & {$[46]$} \\
\hline 17 & 34.64 & $\begin{array}{l}\text { 4h-pyran-4-one, 2,3-dihydro- } \\
\text { 3.5-dihydroxy-6methyl- }\end{array}$ & & 1.54 & $\begin{array}{l}\text { compound with flavonoid fraction, } \\
\text { important bioactive chemical, exhibits } \\
\text { antifungal activity to inhibit growth or } \\
\text { spore germination }\end{array}$ & {$[47]$} \\
\hline 18 & 34.92 & $\begin{array}{c}\text { 2-propen-1-ol,3-phenyl- } \\
\text { (hydroxytyrosol) }\end{array}$ & $\mathrm{C}_{9} \mathrm{H}_{10}$ & 24.07 & antioxidant, antiinflammatory & {$[48]$} \\
\hline 19 & 35,06 & tricosane & $\mathrm{C}_{23} \mathrm{H}_{48}$ & 1,50 & $\begin{array}{l}\text { antimicrobial activity, } \\
\text { radical scavenging effect }\end{array}$ & {$[49]$} \\
\hline 20 & 36.86 & benzofuran & $\mathrm{C}_{8} \mathrm{H}_{6} \mathrm{O}$ & 1.48 & $\begin{array}{l}\text { antioxidants, used in preparation of } \\
\text { rubber, as medicines }\end{array}$ & [49] \\
\hline 21 & 37.78 & $\begin{array}{l}\text { 2-butonic acid, 2-methyl-, } \\
\text { 3-methylbutil ester }\end{array}$ & $\mathrm{C}_{10} \mathrm{H}_{18} \mathrm{O}_{2}$ & 14.71 & flavoring agents & {$[50]$} \\
\hline 22 & 44.89 & n-hexadecanoic acid & $\mathrm{C}_{16} \mathrm{H}_{32} \mathrm{O}_{2}$ & 2.37 & $\begin{array}{c}\text { anti-inflammatory, antioxidant, } \\
\text { hypocholesterolemic, antibacterial, } \\
\text { activities }\end{array}$ & {$[50]$} \\
\hline 23 & 45.04 & 1-docosanol, acetate & $\mathrm{C}_{22} \mathrm{H}_{46} \mathrm{O}$ & 1.52 & $\begin{array}{c}\text { saturated fatty alcohol antiviral agent, } \\
\text { used traditionally as an emollient, } \\
\text { emulsifier, and thickener in cosmetics, } \\
\text { and nutritional supplement (as an } \\
\text { individual entity and also as a constituent } \\
\text { of policosanol) }\end{array}$ & {$[51]$} \\
\hline 24 & 46,08 & behenic alcohol & $\mathrm{C}_{22} \mathrm{H}_{46} \mathrm{O}$ & 1,04 & $\begin{array}{l}\text { antiviral agent, in humans causes an } \\
\text { increase in blood cholesterol }\end{array}$ & {$[52]$} \\
\hline 25 & 46.45 & 4-hydroxy-benzeneethanol & $\mathrm{C}_{8} \mathrm{H}_{10} \mathrm{O}_{2}$ & 12.45 & $\begin{array}{c}\text { phenolic antioxidant, } \\
\text { used as a pharmaceutical intermediate } \\
\text { to produce metoprolol, betaxolol and } \\
\text { salidroside, etc. }\end{array}$ & {$[52]$} \\
\hline 26 & 47.21 & squalene & $\mathrm{C}_{30} \mathrm{H}_{50}$ & 1.55 & $\begin{array}{c}\text { antihypoxant, intermediate in the } \\
\text { biological synthesis of steroids, including } \\
\text { cholesterol (through lanosterol), } \\
\text { participates in metabolism }\end{array}$ & {$[53]$} \\
\hline 27 & 48.15 & tetracosyl acetate & $\mathrm{C}_{26} \mathrm{H}_{52} \mathrm{O}_{2}$ & 2.30 & used as a component of fruit essences & {$[54]$} \\
\hline 28 & 46.97 & n-tetracosanal-1 & $\mathrm{C}_{24} \mathrm{H}_{48} \mathrm{O}$ & 2.97 & not fully explored & {$[54]$} \\
\hline
\end{tabular}


According to the results presented in the Table 1, 28 compounds were identified using GC-MS analysis: of which $\beta$-pinene was found in the greatest amount $(0.98 \%), 1,3$-cyclopentadiene, 5,5-dimethyl2-ethyl benzene1-methyl-3-(1-methyl1), ethanone, 2-hydroxy-1-phenyl-, 2-propanone, 1-hydroxy-, citral, 2.6-dimethyl-1,3,5,7-octatetraene,e,e-, acetic acid, propanoic acid, 2-oxo-, methyl ester, 2-furanmethanol, 2.6-octadienal, 3,7-dimethyl-, geraniol, benzyl-alcohol, cinnamaldehyde, 1,3-diaxol-2-one, 4.5-dimethyl-, 2-hydroxy-gamma-butyrolactone, 4h-pyran-4-one, 2,3 dihydro-3.5-dihidroxy-6-methyl-, 2-propen-1-ol, 3-phenyl-, tricosane, benzofuran, 2-butonic acid, 2-methyl-3-methylbutill ester, n-hexadecanoic acid, 1-docosanol, acetate, behenic alcohol, benzeneethano 1,4-hydroxy-, squalene, tetracosyl acetate, n-tetracosanal-1.

It should be noted that 2-(4-hydroxyphenyl) ethanol serves as a pharmaceutical intermediate for metoprolol, betaxolol and salidroside. Metoprolol is a beta-adrenergic blocking agent and is used to treat high blood pressure. Betaxolol is a cardioselective 1-adrenergic blocker, whereas salidrozide can enhance immunity, slow down aging, resist radiation and tumors and protect the cardiovascular system, etc. [34].

Lipophilic compounds exhibit a wide range of biological activities, e.g., cinnamaldehyde, contained in the quantity of $6.26 \%$, may serve as a hypoglycemic agent, EC 4.3.1.24 (phenylalanine ammonia-lyase) inhibitor, vasodilator, antifungal agent, flavoring agent, plant metabolite and sensitizer [44].

Hydroxytyrosol - one of the main phenolic components of the roots $(24.07 \%)$, is also beneficial for health, its protective action has been shown in preclinical studies against several diseases.

Numerous studies have demonstrated the importance of natural dietary polyphenols in supporting cardiovascular health. Reactive oxygen species (ROS) are critically involved in the endothelial dysfunction that contributes to atherosclerosis development. Oxidative stress-induced endothelial dysfunction probably represents one of the first stages in the development of atherosclerotic lesions. Accordingly, walls of atherosclerotic vessels contain increased levels of ROS, which affect several redox-sensitive pathways in vascular cells, resulting in a markedly altered cellular composition of the tissue. Migration and proliferation of vascular smooth muscle cells in the area is induced, as well as expression of adhesion molecules and chemotactic factors by the endothelium. Direct reduction of ROS levels and/or stimulation of antioxidant defense at these levels could possibly help to avoid the development of atherosclerosis. Mechanisms of action include potent antioxidant and antiinflammatory effects, among others [48].

P-tyrosol, contained in the quantity of $12.45 \%$, is recognized as a good antioxidant, which counteract the damaging effects of oxidation in animal tissues. Anti-arrhythmia agents are often divided into four main groups according to their mechanisms of action: sodium channel blockade, beta-adrenergic blockade, repolarization prolongation, or calcium channel blockade [49]. Agents used for the treatment or prevention of cardiac arrhythmias may affect the polarization-repolarization phase of the action potential, its excitability or refractoriness, impulse conduction or membrane responsiveness within cardiac fibers. Another important compound is squalene [53].

By chemical composition, the essential oil, obtained from the rhizomes of $R$. rosea differs in composition. The composition of the oil is affected by the place of plant growth. As known from the literature data, main components of the essential oil of $R$. rosea grown in Bulgaria are geraniol and myrtenol [55], in China - geraniol and octanol [56], and in India - phenylethyl alcohol [57], in Kazakhstan for the first-time cinnamon alcohol was found, and earlier cinnamon alcohol was found only in samples from Bulgaria [55]. Based on the our results, it can be concluded that, as representatives of a succulent species, $R$. rosea contains in plant roots not only a set of vitamin groups, but also biologically active compounds that, according to conducted research and literature review, can favorably affect the human body.

\section{Conclusion}

Rhodiola rosea L. is a plant with a whole spectrum of biological activities (increases mental activity in healthy people; reduces anxiety and fear with fatigue syndrome; significantly increases the amount of dynamic and static work; normalizes metabolic processes). According to the literature data, plant roots contain essential oil, tannins, more than 20 valuable trace elements, like iron, phosphorus, magnesium, manganese, etc., ascorbic and nicotinic acids.

As mentioned, before GC-MS (Agilent $6890 \mathrm{~N} / 5973 \mathrm{~N}, \mathrm{USA}$ ) analysis was used for identification and quantitative estimation of compounds in the plant. Data obtained in this work includes the general chemical profile of the essential oil, percentage content and retention could be useful in estimating its chemical characteristics. Such components as $\beta$-pinene (0.98\%), benzene 1-methyl-3-(1-methyl 1) $(0.70 \%)$, 2-furanmethanol $(0.96 \%)$ were identified 
in small amounts, largest amount was revealed for 2-propen-1-ol,3-phenyl (24.07\%), 2-butonic acid, 2-methyl-3-methylbutil1 ester, (14.71\%) and benzeneethano 1,4-hydroxy (12.45\%). By the profile of their biological activity, proven compounds show high antioxidant potential.

\section{References}

1. Zinchenko E.S. (2014) Rhodiola rosea. In: The Red Book of Kazakhstan, vol. 2. Part 1. Plants, Almaty, p. 133.

2. Vasiliev A.N. (1972) Rhodiola - Rhodiola L. In: Flora of Kazakhstan, Alma-Ata: Publishing House of the Academy of Sciences of the Kazakh SSR, vol. 2, pp. 345-352.

3. Brown R.P., Gerbarg P.L., Ramazanov Z. (2002) Rhodiola rosea: a phytomedicinal overview. Journal of the American Botanical Council, vol. 56, pp. 40-52.

4. Kittredge J.S. (1974) Behavioral bioassays and biologically active compounds. In: Food-drugs from the sea, Proceedings, pp. 467-475.

5. McGuffin M., Kartesz J.T., Leung A.Y., Tucker A.O. (2000) Herbs of Commerce. 2nd ed. Silver Spring, MD: American Herbal Products Association, $421 \mathrm{p}$.

6. Ballmann C.G., Maze S.B., Wells A.C., Marshall M.M., Rogers R.R. (2019) Effects of short-term Rhodiola Rosea (Golden Root Extract) supplementation on anaerobic exercise performance. $J$ Sports Sci., vol. 37, no. 9, pp. 998-1003.

7. Moran R.V. (2009) Rhodiola. In: Flora of North America North of Mexico, ed. by Flora of North America Association, vol. 8, pp. 164-167.

8. European Medicines Agency Committee on Herbal Medicinal Products (2011) Assessment report on Rhodiola rosea L. rhizoma et radix. London, United Kingdom, pp. 1-32.

9. Amsterdam J.D., Panossian A.G. (2016) Rhodiola rosea L. as a putative botanical antidepressant. Phytomedicine, vol. 23, no. 7, pp. 770-783.

10. Kurkin V.A., Zapesochnaya G.G., Shchavlinskii A.N., Nukhimovskii E.L., Vandyshev V.V. (1985) Method of analysis of identity and quality of Rhodiola rosea rhizome. Khim Farm Zh., vol. 19, no. 3, pp. 185-190.

11. WHO (2013) Rhodiola quadrifida Fisch \& Mey and Rhodiola rosea L. Medicinal Plants in Mongolia. Geneva, Switzerland, pp. 163-172.

12. Powdered Rhodiola rosea extract. USP 40NF 35 (2017) Rockville, MD: United States Pharmacopeial Convention, pp. 6809-6810.
13. Yousef G.G., Grace M.H., Cheng D.M., Belolipov I.V., Raskin I., Lila M.A. (2006). Comparative phytochemical characterization of three Rhodiola species. Phytochem., vol. 67, no. 21, pp. 2380-2391.

14. Kurkin V.A. (2015) Rhodiola rosea (Golden root): drugs production and standardization: Monography. Samara: Ofort 1td, Samara State Medical University MHRF, p. 240.

15. Galambosi B. (2005) Rhodiola rosea L. from wild collection to field production. Med Plant Cons., vol. 11, no. 1, pp. 31-35.

16. Galambosi B., Galambosi Zs., Slacanin I. (2007) Comparison of natural and cultivated roseroot (Rhodiola rosea L.) roots in Finland. Z. ArzneiGewurzpfla, vol. 12, no. 3, pp. 141-147.

17. Rohloff J. (2002) Volatiles from rhizomes of Rhodiola rosea L. Phytochem., vol. 59, no. 6, pp. 655-661.

18. Chevallier A. (2016). Encyclopedia of Herbal Medicine. DK/Penguin Random House. p. 127.

19. Furmanowa M., Skopinska-Rozewska E., Rogala E., Malgorzata H. (1998) Rhodiola rosea in vitro culture: phytochemical analysis and antioxidant action. Acta Societis Botanicorum Poloniae. vol. 76, no. 1, pp. 69-73.

20. Bykov B.A., Zapesochnaya G.G., Kurkin B.A. (1999) Rhodiola rosovaya (Rhodiola rosea L.): Tradisionniye y biotechnologichnye aspecti poluchenie lekarstvennih sredstv (obzor) [Rhodiola rose traditional and biotechnological aspects the preparation of medicaments]. Chem Pharm J., vol. 33, no. 1, pp. 28-37.

21. Rhodiola crenulata. In: Pharmacopoeia of the Peoples Republic of China (2010). China Medical Science, vol. 1, pp. 376-377.

22. Rhodiola. In: Wu Y.-Z., Raven P.H., eds. Flora of China. Vol 8. Beijing, China and St. Louis, MO: Missouri Botanical Garden Press, 2001. pp. 251-268. pp. 13.

23. Bohm B.A. (2009) The geography of phytochemical races. Springer, Netherlands, $358 \mathrm{p}$.

24. Krasnov E.A., Vejc L.A. (1968) Issledovanie jefirnogo masla rodioly rozovoj [Research essential oil Rhodiola L.] (Rhodiola rosea L.). In: Central nervous system stimulation. Tomsk. vol. 2, pp. 18-21.

25. Cuerrier A., Ampong-Nyarko K. (2014). Traditional herbal medicines for modern times. Rhodiola rosea. CRC Press, Taylor \& Francis group, $304 \mathrm{p}$.

26. Petkov V.D., Yonkov D., Mosharoff A. et al. (1986) Effects of alcohol aqueous extract from Rhodiola rosea L. roots on learning and memory. Acta Physiol Pharmacol Bulg., vol. 12, no. 1, pp. 3-16. 
27. Mattson M.P., Pedersen W.A., Duan W., Culmsee C., Camandola S. (1999) Cellular and molecular mechanisms underlying perturbed energy metabolism and neuronal degeneration in Alzheimer's. Ann NY Acad Sci., vol. 893, pp. 154-175.

28. Simonova N.V., Dorovskih V.A., Shtarberg M.A. (2011) Adaptogeny $\mathrm{v}$ korrekcii processov perekisnogo okislenija lipidov biomembran, inducirovannyh vozdejstviem holoda i ul'trafioletovyh luchej [Adaptogens in the correction of lipid peroxidation of biomembranes induced by exposure to cold and ultraviolet rays]. Bulletin of physiology and $p a-$ thology of respiration, no. 40, pp. 66-71.

29. Kulagin O.L., Kurkin V.A., Careva A.A., Dodonova N.A. (2010) Primenenie fitopreparatov rodioly rozovoj v kachestve vozmozhnyh gepatoprotektorov [The use of herbal remedies Rhodiola Rosea as possible hepatoprotectors]. Proceedings of the Samara Scientific Center of the Russian Academy of Sciences, vol. 12, no. 1-8, pp. 2065-2068.

30. Sal'nik A.S., Cherdyncev S.G., Eulusheva V.A., Kapustina V.A. (1968) K mehanizmu stimulirujushhego dejstvija jekstrakta jeleuterokokka, rodozina i piridrola pri myshechnyh nagruzkah [The mechanism of the stimulating effect of the extract of Eleutherococcus, rhodosin and pyridrol under muscle loads]. In: Stimulants of the central nervous system. Tomsk, vol. 2, pp. 89-91.

31. Simonova N.V. (2009) Phytodrugs in correction of lipids peroxidation processes of biomembranes, induced by UV radiation. Reporter of Krasnoyarsk State Agrarian University, no. 2, pp. 119-125.

32. Gosudarstvennaja Farmakopeja RK. [State Pharmacopoeia RK], 2008, vol. 1, 591 p.

33. Gosudarstvennaja Farmakopeja RK. [State Pharmacopoeia RK], 2009, vol. 2, 802 p.

34. Rivas da Silva A.C., Monteiro Lopes P., Barros de Azevedo M.M. et al. (2012) Biological Activities of aMyrzagaliyeva A.B., Ibatayev Zh.A., Iskakova Zh.B., Samarkhanov T.N., Medeubayeva B.Z. Himija rastitel'nogo syr'ja [Chemistry of plant material], $1 / 05$, no. $3,72 \mathrm{p}$.

35. Rodin I.A., Smirnov R.S., Smolenkov A.D., Krechetov P.P., Shpigun O.A. (2012) Transformation of unsymmetrical dimethylhydrazine in soil. Eur Soil Sci., Maik Nauka/Interperiodica Publishing. vol. 45, p. 46.

36. Mohandes F., Salavati-Niasari M. (2014) Particle size and shape modification of hydroxyapatite nanostructures synthesized via a complexing agent-assisted route. Materials Science \& Engineering. Materials for Biological Applications, vol. 40, pp. 288-298.

Int. j. biol. chem. (Online)
37. Freitag J., Díez M.T.S., Tuma D.1, Ulanova T.V., Maurer G. (2004) High-pressure multiphase behavior of the ternary systems (ethene + water + 1-propanol) and (ethene + water +2 -propanol): part I: experimental investigation. $J$ Supercrit Fluids, vol. 32, no. 1-3, pp. 1-13.

38. Duarte M.C., Figueira G.M., Sartoratto A., Rehder V.L., Delarmelina C. (2005) Anti-candida activity of Brazilian medicinal plants. J Ethnopharmacol., vol. 97, no. 2, pp. 305-311.

39. El-Sayed A.M., Byers J.A., Manning L.M. et al. (2008) Floral scent of Canada thistle and its potential as a generic insect attractant. J Econ Entomol., vol. 101, no. 3, pp. 720-727.

40. Cortesia C., Vilchèze C., Bernut A. et al. (2014) Acetic acid, the active component of vinegar, is an effective tuberculocidal disinfectant. Chemother., vol. 53, 3197-3204

41. Thompson A.M., Rewcastle G.W., Tercel M. et al. Tyrosine kinase inhibitors. 1. Structureactivity relationships for inhibition of epidermal growth factor receptor tyrosine kinase activity by 2,3-dihydro-2-thioxo-1H-indole-3-alkanoic acids and 2,2'-dithiobis(1H-indole-3-alkanoic acids). Med Chem., vol. 17, pp. 2459-2469.

42. Arnoldi M., Negroni A.D'Agostina (1998) Effect of antioxidants on the formation of volatiles from the Maillard reaction. Dev Food Sci., vol. 40, pp. 529-534.

43. Sun Y., Hayakawa S., Chuamanochan M., Fujimoto M., Innun A., Izumori K. (2006) Antioxidant effects of Maillard reaction products obtained from ovalbumin and different D-aldohexoses. Biosci Biotechnol Biochem., vol. 70, no. 3, pp. 598-605.

44. Bergeron S., Chaplin D.A., Edwards J.H. et al. (2006) Nitrilasecatalyzed desymmetrization of 3-hydroxyglutaronitrile: preparation of a statin sidechain intermediate. Org Process Res Dev., vol. 10, pp. 661-665.

45. Rahuman A.A., Gopalakrishnan G., Ghouse B.S., Arumugam S., Himalayan B. (2000) Effect of Feronia limonia on mosquito larvae. Fitoterapia, vol. 71, pp. 553-555.

46. Goldberg K., Schroer K., Lütz S., Liese A. (2007) Biocatalytic ketone reduction-a powerful tool for the production of chiral alcohols-part II: wholecell reductions. Appl Microbiol Biotechnol., vol. 76, pp. 249-255.

47. Aparna V., Dileep K.V., Mandal P.K., Karthe P., Sadasivan C., Haridas M. (2012) Anti-inflammatory property of n-hexadecanoic acid: structural evidence and kinetic assessment. Chem Biol Drug Res., 
vol. 80 , pp. 434-439.

48. Hollingsworth R.I. (1999) Taming carbohydrate complexity: a facile, high-yield route to chiral 2,3-dihydroxybutanoic acids and 4-hydroxytetrahydrofuran-2-ones with very high optical purity from pentose sugars. J Org Chem., vol. 64, pp. 7633-7634.

49. Kumar P.P., Kumaravel S., Lalitha C. (2010) Screening of antioxidant activity, total phenolics and GC-MS study of Vitex negundo. Afr J Biochem Res., vol. 4, pp. 191-195.

50. Fickert B., Schieberle P. (1998) Nahrung. Food, vol. 42, pp. 371-375.

51. Buttery R.G., Takeoka G.R., Naim M., Rabinowitch H., Nam Y. (2001) Analysis of furaneol in tomato using dynamic headspace sampling with sodium sulfate. JAgric Food Chem., vol. 49, pp. 43494351.

52. De Clercq E., Li G. (2016) Approved antiviral drugs over the past 50 years. Clin Microbiol Rev., vol. 29 , no. 3, pp. 695-747.

53. Wegener R., Schulz S., Meiners T., Hadwich
K., Hilker M. (2001) Analysis of volatiles induced by oviposition of elm leaf beetle Xanthogaleruca luteola on Ulmus minor. J Chem Ecol., vol. 27, no. 3, pp 499-515

54. Zídek Z., Kmonícková E., Holy A. (2005) Biomed. Pap. Med. Fac. Univ. Palacky Olomouc Czech. Repub., vol. 315, p. 149.

55. Kosakowska O., Baczek K., Przybyl J.L. et al. (2018). Antioxidant and antibacterial activity of roseroot (Rhodiola rosea L.) dry extracts. Molecules, vol. 23 , no. 7 , p. 1767.

56. Mao Y., Li Y., Yao N. (2007). Simultaneous determination of salidroside and tyrosol in extracts of Rhodiola L. by microwave assisted extraction and high-performance liquid chromatography. $J$ Pharm Biomed Anal., vol. 45, no. 3, pp. 510-515.

57. Bhardwaj A.K., Singh B., Kaur K., Roshan P. et al. (2018). In vitro propagation, clonal fidelity and phytochemical analysis of Rhodiola imbricata Edgew: a rare trans-Himalayan medicinal plant. Plant Cell Tissue Organ Cult., vol. 135, no. 3, 